\title{
Adaptation of urinary nitrogen excretion in infants to changes in protein intake
}

\author{
BY H. CHAN \\ Medical Research Council, Tropical Metabolism Research Unit, \\ University of the West Indies, Jamaica
}

(Received 28 December 1967-Accepted 4 Fanuary 1968)

\begin{abstract}
r. Thirty-six nitrogen-balance measurements were made on children recovering from malnutrition. Two types of diet were used: a high-protein diet providing from $\mathrm{I} \cdot 25$ to $6.0 \mathrm{~g}$ protein $/ \mathrm{kg}$ per day which supported normal growth, and a low-protein diet providing $0.75 \mathrm{~g}$ protein $/ \mathrm{kg}$ per day on which the children were approximately in $\mathrm{N}$ balance. Both diets provided $\mathrm{I} 20 \mathrm{kcal} / \mathrm{kg}$ per day.

2. The size of the labile protein pool was estimated from the $\mathrm{N}$ lost on changing from a high- to a low-protein diet. After the change of diet a new equilibrium was reached in about 3 days.

3. Labile protein, as defined above, represented about $1 \cdot 2 \%$ of the total body protein on changing from 6.0 to $0.75 \mathrm{~g}$ protein $/ \mathrm{kg}$ per day, and about $0.2 \%$ of total body protein on changing from $\mathrm{I}^{\circ} 5$ to $0.75 \mathrm{~g}$ protein $/ \mathrm{kg}$ per day. The magnitude of the labile protein pool did not appear to be related to the nutritional state of the child.

4. It is concluded that the labile protein pool is not a reservoir which can be filled, but that losses of $\mathrm{N}$ which occur on reducing the protein intake of an infant reflect a lag in metabolic adjustment.
\end{abstract}

It has long been known that when nitrogen intake is altered from a high level to a low level, a net loss of $\mathrm{N}$ occurs from the body before equilibrium is re-established at the lower intake (Voit, I866, I867). Martin \& Robison (I922), in experiments on man, showed that the 'extra' $N$ excreted when the subject was transferred from a high to a low intake was fully regained on returning to the higher intake. In both instances it took 6-8 days for equilibrium to be attained at the new level. This lag in adjustment to an altered level of protein intake has been observed in many animal species other than man. The literature has been fully reviewed by Munro (1964).

Voit (I866) concluded that the extra $\mathrm{N}$ excreted in urine during the initial period of a fast represents loss of labile body protein ('vorrathseiweiss', i.e. circulating or storage protein). Other terms which have been used are 'reserve protein' or 'deposit protein'. Since these terms imply the existence of a discrete type of protein fulfilling a useful role, it is better to use a descriptive term such as 'labile protein'. Munro (1964) defined labile protein as protein which is rapidly dissipated on a low protein intake and rapidly restored on a high one. In the human adult the rapidly mobilized protein may amount to between 3 and $5 \%$ of the total body protein.

Allison and co-workers (Allison, 1950; Allison, Wannemacher \& Banks, 1963; Allison \& Wannemacher, 1965) defined 'protein reserves' as those tissue proteins which can be reversibly depleted and repleted, and included labile reserves as part of the total reserves. Total reserves can amount to as much as $25 \%$ of body $\mathrm{N}$. Indeed, Allison's rats lost about $50 \%$ of their body $\mathrm{N}$ before they succumbed on the proteinfree diet. Waterlow, Cravioto \& Stephen (I960) suggested that the body proteins can 
be separated roughly into 'fixed' and 'mobile' fractions. From the results of Darrow \& Hellerstein (I958) and of Fuhrman, Watson \& Crismon (I95I) it was estimated that the 'mobile' fraction accounts for rather more than half the total body protein in the adult, and for rather less than half in the newborn infant.

Obviously, there is no clear dividing line between a small loss of so-called labile protein, which may be physiological, i.e. compatible with normal function, and severe depletion of the mobile protein of most tissues, which must surely be regarded as pathological. An empirical solution to this problem was proposed by the Joint FAO/WHO Expert Group on Protein Requirements (WHO, 1965). When the N intake is altered from a high to a low level, the curve of urinary $N$ excretion may be divided into two parts. Initially there is a rapid fall, which, as Martin $\&$ Robison (1922) showed, follows an exponential course. In their experiments the time constant was such that the rate of fall had decreased almost to zero by $6-8$ days. After this time, if the subject is on a diet which covers his maintenance requirements, the $\mathrm{N}$ excretion remains constant. If he is on a protein-free diet there is a continuing slow fall in urinary $\mathrm{N}$ excretion, so that a fixed level of 'endogenous' $\mathrm{N}$ loss is never reached (Deuel, Sandiford, Sandiford \& Boothby, I928; Murlin, Edwards, Hawley \& Clark, 1946; Swanson, 1959). The Joint FAO/WHO Expert Group suggested that the extra $\mathrm{N}$ excreted during the initial phase, when the curve is falling rapidly, represents loss of labile protein. Thereafter, if a negative $\mathrm{N}$ balance persists, it represents true tissue depletion. If labile protein is regarded as a kind of protein reserve, the amount of extra $\mathrm{N}$ lost during the first phase may be used as a measure of the size of the reserve. The results of Thomas (I9I0) on man, and of Campbell \& Kosterlitz (I948) on rats suggest that the amount of labile protein does not exceed about $5 \%$ of the total body $\mathrm{N}$. There appears, however, to be no information about the way in which the amount of labile protein may vary under different conditions, nor has it been measured in infants, in whom, because of their high protein requirements, the question of a reserve protein must be of critical importance.

The present work was undertaken with three objectives: to investigate the pattern of urinary $\mathrm{N}$ adaptation in the infant; to determine the extent of the excess loss or gain of $\mathrm{N}$ above the basal as a measure of the amount of labile protein; to find whether undernourished and normal children have different amounts of labile protein.

\section{EXPERIMENTAL}

The subjects were male infants aged from 7 to 26 months who were recovering, or had recovered, from malnutrition. No patients were studied until any electrolyte disturbances or infections present on admission to hospital had been treated, and until recovery, as shown by weight gain, had begun. In this Unit a child is considered to have recovered from malnutrition when he has regained the normal weight for his height, even though at this stage he may still be below the expected weight for his age. The expected or 'normal' standards for weight and height were those of North American children (Nelson, I959). 


\title{
Design of the experiment
}

The studies were mainly concerned with adaptation from a high to a low protein intake. In all the tests the low intake was that required for maintenance, i.e. I $20 \mathrm{mg} \mathrm{N}$ or $0.75 \mathrm{~g}$ protein per $\mathrm{kg}$ body-weight per day (Chan \& Waterlow, 1966). According to the higher level of protein intake the subjects were divided into three groups.

Group $A$. The high level of protein intake was about $6 \mathrm{~g} / \mathrm{kg}$ per day. This very high level was chosen in order to bring out as clearly as possible the changes that occurred during adaptation. The objectives were to establish the length of time needed for equilibration after changing the protein intake, and to compare the loss on changing from a high to a low intake with the gain when the high intake was resumed. Six patients were studied. The detailed plan was as shown in Table I.

\section{Table I. Group A: detailed plan of experiment}

$\begin{aligned} \text { Days } & \\ \mathrm{I}-4 & \text { Equilibration on high protein intake (about } 6 \mathrm{~g} / \mathrm{kg} \text { per day) } \\ 5-7 & \text { High protein intake; } \mathrm{N} \text { balance } \\ 8-9 & \text { High protein intake; rest days } \\ 10-12 & \text { Low protein intake }(0.75 \mathrm{~g} / \mathrm{kg} \text { per day); } \mathrm{N} \text { balance; adaptation period } \\ 13-15 & \text { Low protein intake; rest days } \\ \mathrm{I} 6-18 & \text { Low protein intake; } \mathrm{N} \text { balance } \\ 19 & \text { Low protein intake; rest day } \\ 20-22 & \text { High protein intake; } \mathrm{N} \text { balance; adaptation period } \\ 23-25 & \text { High protein intake; rest days } \\ 26-28 & \text { High protein intake; } \mathrm{N} \text { balance }\end{aligned}$

\section{Table 2. Group B: detailed plan of experiment}

Days

$I-4$
$5-6$

7

8-10

Equilibration; intake of $3-4 \mathrm{~g}$ protein/kg per day

Intake of $3-4 \mathrm{~g}$ protein $/ \mathrm{kg}$ per day; $\mathrm{N}$ balance

Intake of $3-4 \mathrm{~g}$ protein $/ \mathrm{kg}$ per day

Low protein intake $(0.75 \mathrm{~g} / \mathrm{kg}$ per day; $\mathrm{N}$ balance $)$

\section{Table 3. Group C: detailed plan of experiment}

Days

$1-20$

$2 \mathrm{I}-23$

$24-25$

$26-27$

\author{
Intake of $1 \cdot 25-\mathrm{I} \cdot 75 \mathrm{~g}$ protein $/ \mathrm{kg}$ per day \\ Low protein intake $(0.75 \mathrm{~g} / \mathrm{kg}$ per day); $\mathrm{N}$ balance \\ Low protein intake \\ Low protein intake; $\mathrm{N}$ balance
}

Group $B$. The upper level of protein intake was reduced to $3^{-4} \mathrm{~g} / \mathrm{kg}$ per day, to approximate to that which might be received by a well-fed child in a well-developed country. The scheme was shortened to make it possible for the same child to be tested twice, and the second part of the cycle - transfer from low to high intake-was omitted. It was a weakness of this experimental design that there was no equilibration period on the low protein intake after the period of adaptation. Four subjects were studied once and seven subjects twice, at different stages of recovery. The detailed scheme was as shown in Table 2.

Group $C$. The upper level of protein intake was further reduced to between $1 \cdot 25$ 
and $\mathrm{r} .75 \mathrm{~g}$ protein $/ \mathrm{kg}$ per day. Twelve subjects were studied after they had received this amount for 3 weeks. During that time they gained more weight and retained more $\mathrm{N}$ than normal children of the same weight growing normally. It was therefore considered that this level of intake was adequate for growth (Chan \& Waterlow, 1966). The scheme was as shown in Table 3 .

\section{Diet}

The feeds were liquid mixtures of skim milk (the skim-milk powder used contained $35-45 \%$ protein), cane sugar, maize starch, and arachis oil homogenized in an electric blender. The subjects were given $120 \mathrm{ml} / \mathrm{kg}$ per day of the milk mixture with the amounts of the ingredients adjusted to give the patient $\mathrm{t} 20 \mathrm{kcal} / \mathrm{kg}$ per day. Folic acid ( $\mathrm{mg}$ twice daily), ferrous sulphate ( $75 \mathrm{mg}$ twice daily) and cod-liver oil were given routinely.

\section{Measurement of labile protein}

Urine was collected for $12 \mathrm{~h}$ periods, stools for periods of $24 \mathrm{~h}$. The methods of collection, and of the measurement of intake, were those previously described from this Unit (Waterlow \& Wills, 1960). Feeds, urine and stools were analysed for $\mathrm{N}$ in duplicate by a micro-Kjeldahl method.

Table 4. Example of the method of calculating labile nitrogen lost or gained by a child in group $A$

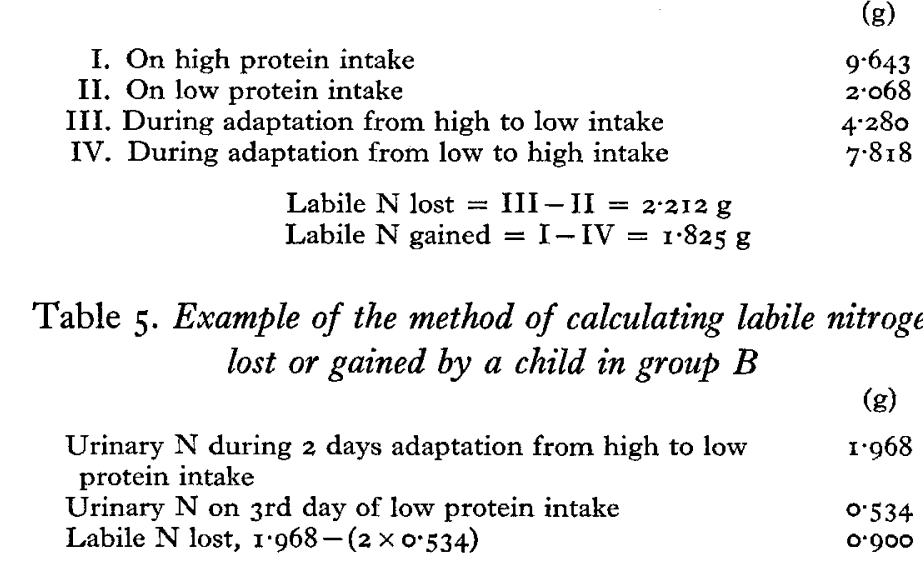

Method of calculation. The labile $\mathrm{N}$ lost or gained has been calculated as the difference between the urinary $\mathrm{N}$ excreted during the period of adaptation and the $\mathrm{N}$ excreted after a steady state had been reached at the new level. This may be illustrated by an example taken from the studies in group A (Table 4 ).

In the studies of group B the child was not kept on the low-protein diet long enough for the basal excretion to be measured. It was therefore assumed that the excretion

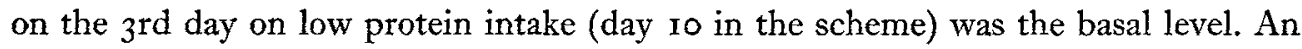
example of the calculation is shown in Table 5 .

To the extent that adaptation might not have been complete after $48 \mathrm{~h}$, the amount of labile protein would be underestimated. 
An alternative method, which has not been adopted, is to calculate labile $\mathrm{N}$ as the net $\mathrm{N}$ balance, positive or negative, during the adaptation period. If the low protein intake were at or above the maintenance level, this method would give the same result as the previous one. If, however, the subject were adapting from a high protein intake to a protein-free diet, the negative $\mathrm{N}$ balance as a measure of labile $\mathrm{N}$ would be in error by the amount of the obligatory or endogenous $\mathrm{N}$ loss. This source of loss is not properly included in the definition of labile $\mathrm{N}$.

In the method of calculation adopted, no account has been taken of faecal $\mathrm{N}$ excretion. Changes in faecal $\mathrm{N}$ are of little significance, since it has been shown previously that the true absorption rate of milk protein by infants recovering from malnutrition approaches $95 \%$ (Waterlow \& Wills, 1960). Moreover, since in practice stools were passed irregularly, but urine was collected for $12 \mathrm{~h}$ periods, the urinary and faecal collections could not be made to coincide.

\section{RESULTS AND DISCUSSION}

The results obtained in the three groups of tests are shown in Tables 6-8. The infants were weighed on the day the protein intake was lowered. Total body $\mathrm{N}$ was taken as $2.5 \%$ body-weight (Stearns, Newman, McKinley \& Jeans, I958) and changes in body protein were calculated as 6.25 times $\mathrm{N}$ gained or lost. Fig. I illustrates the pattern of urinary $\mathrm{N}$ excretion in a typical study in group $\mathrm{A}$.

Table 6. Loss and gain of labile protein by the infants of group $A$ on changing from high to low, and then back to high protein intake

(Upper level of protein intake $=6 \mathrm{~g} / \mathrm{kg}$ per day; lower level of protein intake $=0.75 \mathrm{~g} / \mathrm{kg}$ per day)

\begin{tabular}{|c|c|c|c|c|c|c|c|c|c|c|}
\hline \multirow[b]{2}{*}{ Subject } & \multicolumn{2}{|c|}{$N(g)$} & \multicolumn{2}{|c|}{ Protein (g) } & \multirow{2}{*}{$\begin{array}{c}\text { Body - } \\
\text { weight } \\
\text { (kg) }\end{array}$} & \multirow{2}{*}{$\begin{array}{l}\text { Body } \\
\text { protein* } \\
\text { (g) }\end{array}$} & \multicolumn{2}{|c|}{$\begin{array}{l}\text { Body protein } \\
(\%)\end{array}$} & \multicolumn{2}{|c|}{$\begin{array}{l}\text { g protein } / \mathrm{kg} \\
\text { body-weight }\end{array}$} \\
\hline & Loss & Gain & Loss & Gain & & & Loss & Gain & Loss & Gain \\
\hline LF & $2 \cdot 221$ & $I \cdot 825$ & 13.9 & $x \times 4$ & 6.08 & $95^{\circ}$ & $\mathrm{I} \cdot 47$ & $I \cdot 20$ & $2 \cdot 29$ & $\mathrm{I} \cdot 88$ \\
\hline $\mathrm{CN}$ & 2.023 & $2 \cdot 516$ & 12.6 & 15.6 & $6 \cdot 80$ & 1062 & $I \cdot 19$ & $I \cdot 48$ & $\mathrm{I} \cdot 85$ & 2.07 \\
\hline $\mathrm{RC}$ & $1 \cdot 523$ & $4 \cdot 875$ & $9 \cdot 5$ & 30.4 & 7.05 & Iror & 0.87 & $2 \cdot 80$ & $\mathrm{I} \cdot 35$ & 4.30 \\
\hline $\mathrm{LB}$ & 2.455 & 4.770 & $15 \cdot 3$ & 29.8 & $7 \cdot 15$ & III 7 & I.38 & $2 \cdot 68$ & $2 \cdot 14$ & $4 \cdot 17$ \\
\hline JG & $1 \cdot 334$ & 3.090 & $8 \cdot 35$ & 19.3 & 6.67 & 1041 & 0.80 & $I \cdot 86$ & $\mathrm{I} \cdot \mathbf{2 5}$ & $2 \cdot 90$ \\
\hline MS & $3 \cdot 294$ & $1 \cdot 885$ & $20 \cdot 6$ & $1 x \cdot 8$ & $7 \cdot 82$ & 1222 & $r \cdot 70$ & 0.98 & $2 \cdot 64$ & I. 5 I \\
\hline
\end{tabular}

It is evident from Fig. I that equilibration in both directions was achieved after 3 days. In the adult, 5-7 days are needed (Martin \& Robison, 1922). Deuel et al. (1928), also in the adult, noticed that it took as long as 9 days before there was a sharp change in the slope of the curve of urinary $\mathrm{N}$ plotted against time.

When the protein intake was changed from low to high, adaptation seemed to occur rather more rapidly than when the change was in the opposite direction.

Table 6 shows that, when adaptation was studied in both directions, the gains on the whole were greater than the losses. The mean gain on changing from a low to a high intake was $2 \cdot 80 \mathrm{~g}$ protein $/ \mathrm{kg}$ and the average loss with the reverse change was $\mathrm{r} \cdot 92 \mathrm{~g} / \mathrm{kg}$. A similar observation was made by Thomas (19ro) in an experiment on himself. On 
changing from a protein-free to a high-protein diet he stored $66 \mathrm{~g} \mathrm{~N}$; on resuming the protein-free diet he excreted in the first 7 days $47 \mathrm{~g} \mathrm{~N}$ more than the endogenous level. On the other hand, in the experiments of Martin \& Robison (I922) the gains and losses were said to be equal. Presumably the difference in the present experiments arose because the children were growing, and therefore, on being changed from a low to a high protein intake, were laying down new tissue as well as making good the losses incurred on the low intake.

Table 7. Labile protein lost by the infants of group $B$ when their protein intake was reduced from $3^{-4} \mathrm{~g}$ to $0 \cdot 75 \mathrm{~g} / \mathrm{kg}$ per day

\begin{tabular}{|c|c|c|c|c|c|c|}
\hline Subject & $\begin{array}{l}\text { N loss } \\
\text { (g) }\end{array}$ & $\begin{array}{l}\text { Protein } \\
\text { loss }(g)\end{array}$ & $\begin{array}{c}\text { Body-weight } \\
(\mathrm{kg})\end{array}$ & $\begin{array}{l}\text { Body } \\
\text { protein* } \\
\text { (g) }\end{array}$ & $\begin{array}{c}\text { Body } \\
\text { protein lost } \\
(\%)\end{array}$ & $\begin{array}{c}\text { g Protein } \\
\text { lost } / \mathrm{kg} \\
\text { body-weight }\end{array}$ \\
\hline VB & $\mathrm{I} \cdot 60_{3}$ & $10 \cdot 0$ & 6.88 & 1065 & 0.94 & $I \cdot 45$ \\
\hline NM & 0.500 & $3 \cdot 12$ & $4 \cdot 0$ & 620 & $0.5^{\circ}$ & 0.78 \\
\hline $\mathrm{CB}$ & 0.612 & 3.8 & $4 \cdot 50$ & 697 & 0.55 & 0.85 \\
\hline LC & 0.447 & $2 \cdot 8$ & 3.78 & 585 & 0.48 & 0.74 \\
\hline $\begin{array}{r}\mathrm{JF}(\mathrm{I}) \\
(\mathrm{z})\end{array}$ & $\begin{array}{l}0 \cdot 350 \\
x \cdot 172\end{array}$ & $\begin{array}{l}2 \cdot 2 \\
7 \cdot 3\end{array}$ & $\begin{array}{l}5 \cdot 32 \\
8 \cdot 08\end{array}$ & $\begin{array}{r}825 \\
1250\end{array}$ & $\begin{array}{l}0.27 \\
0.58\end{array}$ & $\begin{array}{l}0.41 \\
0.90\end{array}$ \\
\hline $\begin{array}{r}H G(1) \\
(2)\end{array}$ & $\begin{array}{l}0.870 \\
1 \cdot 383\end{array}$ & $\begin{array}{l}5.45 \\
8.65\end{array}$ & $\begin{array}{l}4 \cdot 84 \\
8 \cdot 0\end{array}$ & $\begin{array}{r}750 \\
1240\end{array}$ & $\begin{array}{l}0.73 \\
0.70\end{array}$ & $\begin{array}{l}\mathbf{I} \cdot 12 \\
\mathrm{I} \cdot 08\end{array}$ \\
\hline $\begin{array}{r}\mathrm{JC}(\mathrm{I}) \\
(2)\end{array}$ & $\begin{array}{l}0.785 \\
I \cdot 057\end{array}$ & $\begin{array}{l}4 \cdot 9 \\
6 \cdot 6\end{array}$ & $\begin{array}{l}6 \cdot 04 \\
8 \cdot 15\end{array}$ & $\begin{array}{r}935 \\
1265\end{array}$ & $\begin{array}{l}0.52 \\
0.52\end{array}$ & $\begin{array}{l}0.8 \mathrm{I} \\
0.8 \mathrm{I}\end{array}$ \\
\hline $\begin{array}{r}\mathrm{AW}(1) \\
(2)\end{array}$ & $\begin{array}{l}0.900 \\
0.940\end{array}$ & $\begin{array}{l}5 \cdot 6 \\
5 \cdot 9\end{array}$ & $\begin{array}{l}4 \cdot 53 \\
6 \cdot 30\end{array}$ & $\begin{array}{l}705 \\
975\end{array}$ & $\begin{array}{l}0.80 \\
0.6 \mathrm{I}\end{array}$ & $\begin{array}{l}I \cdot 24 \\
0.94\end{array}$ \\
\hline $\begin{array}{r}\text { RW (I) } \\
\text { (2) }\end{array}$ & $\begin{array}{l}0.477 \\
1 \cdot 191\end{array}$ & $\begin{array}{l}3 \cdot 0 \\
7 \cdot 45\end{array}$ & $\begin{array}{l}4 \cdot 36 \\
5 \cdot 40\end{array}$ & $\begin{array}{l}675 \\
835\end{array}$ & $\begin{array}{l}0.45 \\
0.89\end{array}$ & $\begin{array}{l}0.69 \\
r \cdot 38\end{array}$ \\
\hline $\begin{array}{r}\text { WE (I) } \\
(2)\end{array}$ & $\begin{array}{l}\mathrm{I} \cdot 213 \\
\mathrm{I} \cdot 305\end{array}$ & $\begin{array}{l}7 \cdot 6 \\
8 \cdot 15\end{array}$ & $\begin{array}{l}6 \cdot 8 I \\
8 \cdot 45\end{array}$ & $\begin{array}{l}1055 \\
1310\end{array}$ & $\begin{array}{l}0.72 \\
0.62\end{array}$ & $\begin{array}{l}I \cdot 12 \\
0.97\end{array}$ \\
\hline $\begin{array}{r}\text { SP (I) } \\
(2)\end{array}$ & $\begin{array}{l}0.262 \\
0.865\end{array}$ & $\begin{array}{l}I \cdot 64 \\
5 \cdot 4\end{array}$ & $\begin{array}{l}3 \cdot 85 \\
5 \cdot 37\end{array}$ & $\begin{array}{l}595 \\
830\end{array}$ & $\begin{array}{l}0.28 \\
0.65\end{array}$ & $\begin{array}{l}0.43 \\
\text { I. } 01\end{array}$ \\
\hline
\end{tabular}

Table 8. Labile protein lost by the infants of group $C$ when their protein intake was reduced from $\mathrm{I} \cdot 25-\mathrm{I} \cdot 75 \mathrm{~g}$ to $0 \cdot 75 \mathrm{~g} / \mathrm{kg}$ per day

\begin{tabular}{|c|c|c|c|c|c|c|}
\hline Subject & $\begin{array}{c}\text { N loss } \\
(\mathrm{g})\end{array}$ & $\begin{array}{l}\text { Protein } \\
\text { loss } \\
\text { (g) }\end{array}$ & $\begin{array}{l}\text { Body-weight } \\
\text { (kg) }\end{array}$ & $\begin{array}{c}\text { Body } \\
\text { protein* } \\
\text { (g) }\end{array}$ & $\begin{array}{c}\text { Body } \\
\text { protein lost } \\
(\%)\end{array}$ & $\begin{array}{l}\text { g Protein } \\
\text { lost } / \mathrm{kg} \\
\text { body-weight }\end{array}$ \\
\hline $\mathrm{JC}$ & 0.729 & $4 \cdot 55$ & $8 \cdot 76$ & 1360 & 0.33 & 0.52 \\
\hline $\mathrm{DM}$ & 1.087 & $6 \cdot 80$ & 10.03 & I 559 & 0.44 & 0.68 \\
\hline $\mathrm{HG}$ & 0.539 & $3 \cdot 37$ & $5 \cdot 99$ & 930 & 0.36 & 0.56 \\
\hline LN & 0.327 & $2 \cdot 04$ & $9 \cdot 5$ & 1470 & 0.14 & 0.21 \\
\hline $\mathrm{CB}$ & 0.090 & 0.56 & $6 \cdot 65$ & 1030 & 0.05 & 0.08 \\
\hline MG & -0.150 & \multicolumn{5}{|c|}{ Positive balance } \\
\hline EM & 0.361 & $2 \cdot 25$ & 10.4 & 1610 & 0.14 & 0.22 \\
\hline $\mathrm{SM}$ & 0.108 & 0.67 & $7 \cdot 79$ & 1210 & 0.05 & 0.09 \\
\hline NS & 0.419 & $2 \cdot 6$ & $8 \cdot 3 \mathrm{I}$ & 1290 & 0.20 & $0.3 \mathrm{I}$ \\
\hline $\mathrm{AW}$ & 0.200 & $1 \cdot 25$ & $7 \cdot 24$ & 1120 & O.II & 0.17 \\
\hline EG & o & 0 & $6 \cdot 10$ & 946 & o & $\circ$ \\
\hline LC & -0.308 & \multicolumn{5}{|c|}{ Positive balance } \\
\hline
\end{tabular}


The results summarized in Table 9 show that the amount of labile $\mathrm{N}$ lost was strongly influenced by the previous protein intake. This was noted also by Voit ( 1866 ).

Even when the initial protein intake had been unphysiologically high, as in group A, the mean loss was only $\mathrm{I} \cdot 2 \%$ of the estimated total body protein. From experiments on adult human subjects (Thomas, 1910; Deuel et al. 1928), dogs (Voit, I866) and rats (Campbell \& Kosterlitz, 1948) it has been concluded that labile protein may amount to between 3 and $5 \%$ of total body protein. The rapidity of adaptation, and the much smaller total loss, illustrate the efficiency of $\mathrm{N}$ economy in the human infant.

\section{Table 9. Labile protein in infants at different levels of protein intake}

(In all groups the lower level of protein intake was $0.75 \mathrm{~g} / \mathrm{kg}$ per day)

\begin{tabular}{|c|c|c|c|c|c|}
\hline \multirow[b]{2}{*}{ Group } & \multirow[b]{2}{*}{$\begin{array}{l}\text { No. of } \\
\text { estimations }\end{array}$} & \multicolumn{2}{|c|}{ Mean loss } & \multicolumn{2}{|c|}{ Mean gain } \\
\hline & & $\begin{array}{l}\text { Body } \\
\text { protein } \\
(\%)\end{array}$ & $\begin{array}{l}\text { g protein } / \mathrm{kg} \\
\text { body-weight }\end{array}$ & $\begin{array}{c}\text { Body } \\
\text { protein } \\
(\%)\end{array}$ & $\begin{array}{l}\text { g protein } / \mathrm{kg} \\
\text { body-weight }\end{array}$ \\
\hline $\begin{array}{l}\text { A; upper level = } 6 \mathrm{~g} \\
\text { protein/kg per day }\end{array}$ & 6 & $\begin{array}{c}I \cdot 23 \\
\mathrm{SD}=0.32\end{array}$ & $\begin{array}{c}\mathrm{I} \cdot 92 \\
\mathrm{SD}=0.5\end{array}$ & $\begin{array}{c}\mathrm{I} \cdot 8 \mathbf{3} \\
\mathrm{SD}=0.7\end{array}$ & $\begin{array}{c}2 \cdot 80 \\
\mathrm{SD}=\mathrm{I} \cdot \mathrm{I}\end{array}$ \\
\hline $\begin{array}{l}\mathrm{B} ; \text { upper level }=3-4 \mathrm{~g} \\
\text { protein } / \mathrm{kg} \text { per day }\end{array}$ & I 8 & $\begin{array}{l}0.60 \\
\mathrm{SD}=0.18\end{array}$ & $\begin{array}{c}0.93 \\
\mathrm{SD}=0.27\end{array}$ & \multicolumn{2}{|c|}{ Not measured } \\
\hline $\begin{array}{l}\mathrm{C} ; \text { upper level }=\mathrm{I} \cdot 25^{-} \\
\mathrm{I} \cdot 75 \mathrm{~g} \text { protein } / \mathrm{kg} \text { per day }\end{array}$ & 12 & $\begin{array}{c}0.18 \\
\mathrm{SD}=0.10\end{array}$ & $\begin{array}{l}0.28 \\
\mathrm{SD}=0.16\end{array}$ & \multicolumn{2}{|c|}{ Not measured } \\
\hline
\end{tabular}

Table 1o. Labile protein and degree of malnutrition in infants

(An arbitrary division has been made at $80 \%$ weight for height)

\begin{tabular}{|c|c|c|c|c|c|}
\hline Subject & $\begin{array}{l}\mathrm{Wt}_{\mathrm{t} / \mathrm{ht}} \\
(\%)\end{array}$ & $\begin{array}{l}\text { Labile protein } \\
\text { (g/kg body-weight) }\end{array}$ & Subject & $\begin{array}{l}\text { Wt/ht } \\
(\%)\end{array}$ & $\begin{array}{l}\text { Labile protein } \\
\text { (g/kg body-weight) }\end{array}$ \\
\hline NM & $5^{2}$ & 0.78 & $\mathrm{SP}(2)$ & 85 & 1.01 \\
\hline SP (I) & 62 & 0.43 & RW (2) & 88 & I. 38 \\
\hline AW (I) & 70 & $I \cdot 24$ & $\mathrm{JF}(2)$ & 90 & 0.90 \\
\hline $\mathrm{JF}(\mathrm{I})$ & 72 & $0.4 \mathrm{I}$ & WE (2) & $9 \mathrm{I}$ & 0.97 \\
\hline $\mathrm{LC}$ & 74 & 0.74 & AW (2) & 92 & 0.94 \\
\hline $\mathrm{CB}$ & 76 & 0.85 & HG (I) & 93 & $\begin{array}{l}1.12 \\
12\end{array}$ \\
\hline VB & 77 & I. 45 & $\mathrm{JC}(2)$ & 96 & $0.8 \mathrm{I}$ \\
\hline RW (I) & 78 & 0.65 & $H G(2)$ & 100+ & 1.08 \\
\hline WE (I) & 79 & $I \cdot 12$ & & & \\
\hline $\mathrm{JC}(\mathrm{I})$ & 79 & $0.8 I$ & & & \\
\hline \multicolumn{3}{|c|}{$\begin{array}{l}\text { Mean labile protein in } \mathrm{g} / \mathrm{kg} \\
\text { body-weight }=0.85(\mathrm{SD}=0.32)\end{array}$} & \multicolumn{3}{|c|}{$\begin{array}{l}\text { Mean labile protein in } \mathrm{g} / \mathrm{kg} \\
\text { body-weight }=\mathrm{I} \cdot 03(\mathrm{SD}=0.16)\end{array}$} \\
\hline
\end{tabular}

The results in Table 7 show that three of the seven subjects who were studied twice lost more labile $\mathrm{N}$ per unit body-weight in the second than in the first study. However, when the amounts of labile protein lost per kg body-weight are related to the degree of weight deficit in each subject (Table ro) it does not seem that the amount of loss bears any relation to the degree of malnutrition. (Student's $t$ test shows that the difference between the means was not significant.)

These findings have some relevance to the problem of the protein requirements of infants. The joint FAO/WHO Expert Group on Protein Requirements (WHO, 1965) concluded that a daily intake of $\mathrm{I} \cdot 25 \mathrm{~g}$ protein $/ \mathrm{kg}$, in terms of protein which was $100 \%$ 
utilized, represented an adequate allowance for a child of I year. Our experience confirms this estimate (Chan \& Waterlow, I966). However, the objection may be made that a child on such a low intake will be at a disadvantage because his 'protein reserves' will be inadequate. This point of view seems untenable, if protein reserves are in any way reflected by the amount of labile protein, as we have defined and measured it. In the first place, the loss of protein which occurs on changing from a normal intake $(3-4 \mathrm{~g} / \mathrm{kg})$ to a maintenance intake is very small, on the average $0.6 \%$ of body protein. It is doubtful if such a loss could have physiological significance. Secondly, the concept of a protein reserve seems to lose all meaning if the size of the reserve is the same in the undernourished and the well-nourished child.

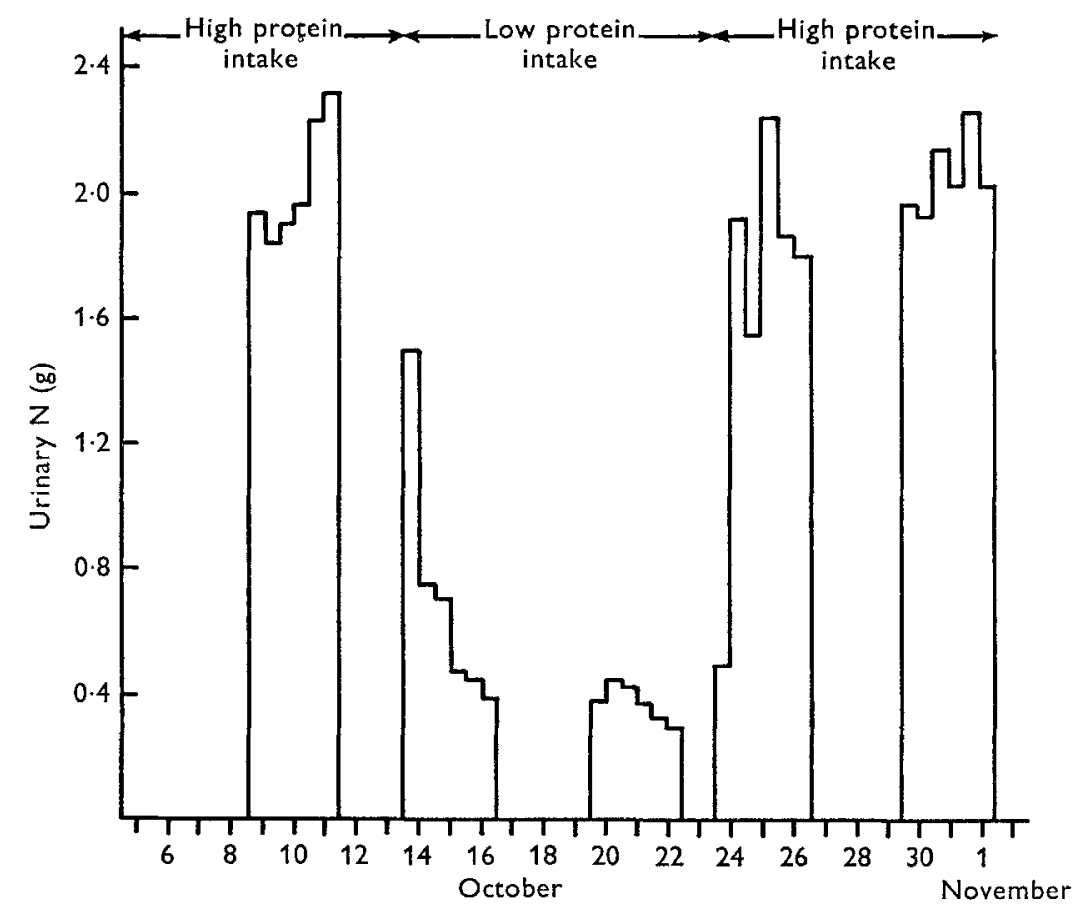

Fig. I Amount of urinary nitrogen excreted by infant $\mathrm{CN}$ during consecutive periods of high, low and high protein intakes ( $\mathrm{g} / 12 \mathrm{~h}$ ).

Experimentally, the level of the protein reserves appears to depend on the intake rather than on the nutritional state; there is no point at which it can be said that the reserves or stores are filled, since the higher the intake the greater the amount of labile protein. This relationship was observed by Henry, Kosterlitz \& Quenouille (I953) and by Henry, Cormack \& Kosterlitz (196I) in their study of the amounts of liver protein in rats receiving different levels of dietary protein. From this it follows that it would be impossible to recommend an optimum intake which would 'fill the protein stores'.

For these reasons, the conclusion from the present work seems to be that labile protein does not represent a reserve or storage protein, but rather that the losses or gains of $\mathrm{N}$ which occur when the protein intake is altered reflect a lag in metabolic adjustment. This aspect of the problem has been discussed by Waterlow, Alleyne, 
Chan, Garrow, Hay, James, Picou \& Stephen (1966), who conclude that adjustment to an altered level of protein intake probably involves adaptive enzyme changes. These may be controlled by hormone action, and cannot be expected to be instantaneous.

We record our gratitude to the World Health Organization for a research grant in support of this work, and to Dr V. N. Patwardhan, Chief of the Nutrition Division, WHO, for his interest and encouragement. Nothing would have been possible without the expertise of the nursing staff and the unfailing help and patience of Professor J. C. Waterlow and Dr J. S. Garrow of this Unit.

\section{REFERENCES}

Allison, J. B. (1950). In Symposia on Nutrition. Vol. 2. Plasma Proteins, p. I23. Springfield, Illinois: C. C. Thomas.

Allison, J. B. \& Wannemacher, R. W. Jr (1965). Am. J. clin. Nutr. 16, 445.

Allison, J. B., Wannemacher, R. W. Jr \& Banks, W. L. Jr (1963). Fedn Proc. Fedn Am. Socs exp. Biol. 22, I 126.

Campbell, R. M. \& Kosterlitz, H. W. (1948). Biochem. F. 43, 416.

Chan, H. \& Waterlow, J. C. (1966). Br. $\mathscr{~}$. Nutr. 20, 775.

Darrow, D. C. \& Hellerstein, S. (1958). Physiol. Rev. 38, i 4.

Deuel, H. J. Jr, Sandiford, I., Sandiford, K. \& Boothby, W. M. (1928). F. biol. Chem. 76, 391.

Fuhrman, F. A., Watson, J. L. \& Crismon, J. M. (I95I). Am. F. Physiol. r67, 305.

Henry, K. M., Cormack, R. M. \& Kosterlitz, H. W. (1961). Br. F. Nutr. x5, 199.

Henry, K. M. Kosterlitz, H. W. \& Quenouille, M. H. (r953). Br. F. Nutr. 7, 5r.

Martin, C. J. \& Robison, R. (1922). Biochem. F. 16, 407.

Munro, H. N. (1964). In Mammalian Protein Metabolism. Vol. I, chapter ro. [H. N. Munro and J. B. Allison, editors.] New York and London: Academic Press Inc.

Murlin, J. R., Edwards, L. E., Hawley, E. E. \& Clark, L. C. (1946). F. Nutr. 31, 533.

Nelson, W. E. (1959). Textbook of Pediatrics, $7^{\text {th }}$ ed., p. 50. Philadelphia and London: W. B. Saunders Co.

Stearns, G., Newman, K. J., McKinley, J. B. \& Jeans, P. C. (I958). Ann. N.Y. Acad. Sci. $69,857$.

Swanson, P. (1959). In Protein and Amino Acid Nutrition. p. 195. [A. A. Albanese, editor.] New York: Academic Press Inc.

Thomas, K. (1910). Arch. Anat. Physiol., Physiol. Abt., Suppl-Band. 249.

Voit, C. (1 866). Z. Biol. 2, 307 .

Voit, C. (1867). Z. Biol. 3, r.

Waterlow, J. C., Alleyne, G. A. O., Chan, H. V., Garrow, J. S., Hay, A., James, P., Picou, D. \& Stephen, J. M. L. (1966). Archos lat.-am. Nutr. 16, I75.

Waterlow, J. C., Cravioto, J. \& Stephen, J. M. L. (1960). Advanc. Protein Chem. 15, 131.

Waterlow, J. C. \& Wills, V. G. (1960). Br. F. Nutr. 14, 183.

WHO (1965). Tech. Rep. Ser. Wld Hlth Org. no. 30 r. 